\title{
Critically appraised topic on adverse food reactions of companion animals (6): prevalence of noncutaneous manifestations of adverse food reactions in dogs and cats
}

\author{
Ralf S. Mueller ${ }^{* *}$ (D) and Thierry Olivry ${ }^{2}$ (D)
}

\begin{abstract}
Background: Many reports describe the cutaneous signs of adverse food reactions (AFR) in the dog and cat. However, various non-cutaneous clinical signs are less well described. Our objective was to systematically evaluate these non-cutaneous signs of AFR in small animals.

Results: We searched two databases (MEDLINE and Web of Science) for pertinent references on non-cutaneous signs of adverse food reactions. Among 117 and 764 articles found in the MEDLINE and Web of Science databases, respectively, we selected 47 articles that reported data related to non-cutaneous clinical signs of AFR. Gastrointestinal signs, symmetrical lupoid onychitis, conjunctivitis, sneezing, and anaphylaxis were reported to be associated with AFR in dogs and gastrointestinal and respiratory signs, conjunctivitis, and hyperactive behaviour in cats. In Border terriers with paroxysmal gluten-sensitive dyskinesia, an underlying AFR should be considered. Of these clinical signs diarrhoea and frequent defecation were most frequently reported to be diet-responsive in dogs; in the cat, these were vomiting and diarrhoea.
\end{abstract}

Conclusions: An elimination diet should be considered early in the work-up of dogs and cats with chronic vomiting and diarrhoea. Other non-cutaneous signs occur less commonly because of AFRs.

Keywords: Canine, Feline, Food allergy, Gastroenteritis, Vomiting, Diarrhoea

\section{Background}

Atopic dermatitis and urticaria are well-recognised clinical features of adverse food reaction (AFR) in the dog $[1,2]$. Cutaneous reaction patterns such as miliary dermatitis, variants of the so-called "eosinophilic granuloma complex" (including oral lesions [3]) and non-inflammatory alopecia have been reported with AFR in cats [4-7]. Non-cutaneous clinical signs are mainly gastrointestinal, but a systematic review of reported non-cutaneous clinical signs is lacking. Our objective was to systematically evaluate those non-cutaneous signs of AFR in dogs and cats.

\footnotetext{
* Correspondence: R.Mueller@lmu.de

'Medizinische Kleintierklinik, Centre for Clinical Veterinary Medicine, LMU

Munich, Veterinaerstrasse 13, 80539 Munich, Germany

Full list of author information is available at the end of the article
}

\section{Clinical scenario}

Consider the example of two patients: A 15-month-old castrated male Jack Russell terrier with chronic diarrhoea and concurrent bilateral conjunctivitis and a six-year-old female spayed domestic shorthaired cat with flatulence and frequent vomiting. You inform the owners of both patients that you suspect that their clinical signs might be caused by a reaction to a component of their pet's diet and you advise that an elimination diet with ingredients not previously fed is indicated for 8 weeks to evaluate a potential food involvement [8]. The owners ask you what clinical signs besides itching and skin problems are frequently reported to be caused by an AFR.

\section{Structured question}

Which are the non-cutaneous clinical signs of AFR reported in dogs and cats and how often do they occur? 


\section{Search strategy}

We searched the Web of Science (Core Collection) and MEDLINE databases using the following string: ((dog* or canine or cat* or feline) and (food* or diet*) and (allerg* or hypersens*)) not (human* or child* or adult*). We limited the search to journal articles published from 1980 to 2017; there were no language restrictions. Bibliographies from selected articles and proceedings of recent conferences in veterinary dermatology and internal medicine were also searched.

\section{Identified evidence}

Our literature search identified 117 and 764 articles in the MEDLINE and Web of Science (Core Collection) databases, respectively. Abstracts of relevant titles were screened and any potentially useful manuscript was downloaded and read. The bibliography of these articles was examined further for additional pertinent citations. In addition, proceedings of recent veterinary dermatology or internal medicine conferences were perused. Altogether, we selected 47 papers that provided usable information.

\section{Evaluation of evidence}

In prospective studies, improvement of a clinical sign with an elimination diet, recurrence after a re-challenge with the previous diet and repeated improvement again when feeding the diet were considered to be strong evidence for an AFR causing that clinical sign. If those conditions were met, but the study was retrospective, we considered the evidence to be only of moderate strength. When improvement occurred upon a change in diet, but a re-challenge with the previous food was not performed, then the evidence was considered weak. The prospective or retrospective nature of some studies was unclear, and we deemed the evidence provided by those reports as of moderate strength. The non-cutaneous clinical signs of AFR, the number of animals affected, as well as the strength of evidence are listed in Table 1 for dogs and in Table 2 for cats.

A high number of dogs and cats with AFR were reported to exhibit vomiting and/or diarrhoea. Although, in many publications, the evidence for a causative AFR was strong [9-21], some cohorts were only retrospective studies $[4,5,22-31]$. Finally, in others groups of animals, the diagnosis of AFR was solely based on an improvement with diet change without report of a re-challenge with the previously fed diet [32-44]. Unfortunately, in a number of articles, these two clinical signs were not listed separately, and patients were reported with "vomiting or diarrhoea" or "gastrointestinal signs" without specifying the number of animals having exhibited each individual sign [7, 9, 14, 15, 17, 24, 25, 28]. Similarly, defecation and tenesmus in dogs [45], and conjunctivitis and drooling in cats [46] were not always clearly distinguished. Of the 395 dogs in which vomiting and diarrhoea were reported individually, 368 dogs (93\%) had diarrhoea, six had vomiting (2\%) and in $21 \operatorname{dogs}(5 \%)$ both clinical signs were present [10, 11, 13, 16, 18, 19, 22, 32, 36, 38-42, 44, 47]. Of the 40 cats with individually reported vomiting and diarrhoea, 15 vomited (38\%), 18 had diarrhoea (45\%) and seven $(18 \%)$ were reported with both clinical signs $[5,20,21,27,29]$. These numbers suggest that

Table 1 Non-cutaneous clinical signs of AFR in dogs

\begin{tabular}{|c|c|c|}
\hline Clinical sign & $\begin{array}{l}\text { Number of animals (\% of all reported } \\
\text { non-cutaneous AFR) }\end{array}$ & Strength of evidence \\
\hline Diarrhoea $[9-19,22-27,32-44,47,48]$ & $391-490^{a}(70-88 \%)$ & $\begin{array}{l}\text { Strong in } 36-39^{a}[9-19,48] \\
\text { Moderate in } 151-189^{a}[22-27,47] \\
\text { Weak in } 204-212^{a}[32-44]\end{array}$ \\
\hline Vomiting $[9,11,13-15,17,18,22-27,33,34,40,42,43]$ & $28-115^{a}(5-21 \%)$ & $\begin{array}{l}\text { Strong in } 6-47^{\mathrm{a}}[9,11,13-15,17,18] \\
\text { Moderate in } 5-43^{\mathrm{a}}[22-27] \\
\text { Weak in } 17-25[33,34,40,42,43]\end{array}$ \\
\hline Increased frequency of defecation $[23,24,45]$ & $33(6 \%)$ & $\begin{array}{l}\text { Strong in } 16[45] \\
\text { Moderate in } 17[23,24]\end{array}$ \\
\hline Tenesmus [45] & $11(2 \%)$ & Strong in 11 \\
\hline Paroxysmal gluten-sensitive dyskinesia of Border terriers [49] & $5(1 \%)$ & $\begin{array}{l}\text { Strong in } 2 \\
\text { Weak in } 3\end{array}$ \\
\hline Symmetrical lupoid onychodystrophy [50] & $4(1 \%)$ & $\begin{array}{l}\text { Strong in } 2 \\
\text { Weak in } 2\end{array}$ \\
\hline Anaphylaxis [40] & $1(0.2 \%)$ & Weak \\
\hline Conjunctivitis [12] & $1(0.2 \%)$ & Strong \\
\hline Asthma [27] & $1(0.2 \%)$ & Moderate \\
\hline Sneezing [14] & $1(0.2 \%)$ & Strong \\
\hline
\end{tabular}

${ }^{a}$ Minimal and maximal number of dogs, as in some studies, the specific number of dogs showing some of the individual clinical signs was not reported 
Table 2 Non-cutaneous clinical signs of AFR in cats

\begin{tabular}{lll}
\hline Clinical sign & $\begin{array}{l}\text { Number of animals (\% of all reported } \\
\text { non-cutaneous AFR) }\end{array}$ & Strength of evidence \\
\hline Diarrhoea $[5,7,20,21,27-31,51]$ & $25-49^{a}(28-55 \%)$ & $\begin{array}{l}\text { Strong in 11-16 }[20,21] \\
\text { Moderate in } 14-33[5,7,27-31] \\
\text { Weak in } 1[51]\end{array}$ \\
Vomiting $[4,5,7,20,21,27-29,31]$ & $26-46^{\mathrm{a}}(29-52 \%)$ & $\begin{array}{l}\text { Strong in 15-20 }[20,21] \\
\text { Moderate in 8-27 }[4,5,7,28,29,31,51]\end{array}$ \\
Conjunctivitis $[4,7,46]$ & $3-20^{\mathrm{a}}(3-22 \%)$ & Strong in $1[7]$ \\
& & Moderate in $1[4]$ \\
Salivating $[46]$ & $1-18(1-20 \%)$ & Weak in 1-18 $[46]$ \\
Respiratory signs $[7]$ & $4(4 \%)$ & Weak \\
Flatulence $[5]$ & $3(3 \%)$ & Moderate \\
Hyperactive behaviour $[6]$ & $1(1 \%)$ & Moderate \\
\hline
\end{tabular}

${ }^{a}$ Minimal and maximal number of cats, as in some studies, the specific number of cats showing some of the individual clinical signs was not reported

AFR-associated vomiting is more prevalent in cats than in dogs. When comparing cutaneous with gastrointestinal signs in dogs and cats (where possible), a bias from authors was apparent. Cutaneous signs predominated when the study had been performed by dermatologists, where $261 \operatorname{dogs}(71 \%)$ and 89 cats $(77 \%)$ showed cutaneous signs only, ten dogs (3\%) and two cats (2\%) showed only gastrointestinal signs and 97 dogs $(27 \%)$ and 23 cats (20\%) showed both gastrointestinal and cutaneous signs. When the studies where performed by internists, 94 dogs $(73 \%)$ and 19 cats $(49 \%)$ showed gastrointestinal signs only, ten dogs $(8 \%)$ and ten cats (26\%) showed cutaneous signs only, and $24 \operatorname{dogs}(19 \%)$ and ten cats (26\%) showed both.

\section{Conclusion and implication for practitioners}

We evaluated 34 articles reporting dogs with noncutaneous clinical signs, 16 of those provided strong evidence, six moderate evidence and 12 weak evidence. In the cat, strong evidence was provided by only three reports, moderate by seven and weak evidence by two. One publication of moderate quality reported on both dogs and cats. Vomiting and diarrhoea were the non-cutaneous signs reported in more than $20 \%$ of dogs and cats with AFR, and an elimination diet with subsequent re-challenge is indicated for those animals early in the diagnostic work-up. In dogs, anaphylaxis, conjunctivitis, increased frequency of defecation, symmetric lupoid onychitis, and sneezing were reported less commonly. In cats, uncommon noncutaneous signs of AFR were conjunctivitis, salivating, flatulence, hyperactive behaviour and respiratory signs and all of these were more often associated with diseases other than an AFR. Depending on the patient's history, other tests should possibly be conducted before an elimination diet or concurrently. The probability of AFR is likely to increase if patients exhibit more than one of the non-cutaneous signs described above.

\section{Abbreviations}

AFR(s): Adverse food reaction(s); CAT: Critically appraised topic

\section{Acknowledgements}

Not applicable.

\section{Funding}

This research was funded by Royal Canin, France. Royal Canin also paid publication charges for this article. This company had no influence on the data collection, interpretation and content of this CAT.

\section{Availability of data and materials}

The datasets supporting the conclusions of this article are included within the article, further details are available in the published manuscripts referenced in the article.

\section{Authors' contributions}

Both authors selected the topic of this CAT. RSM performed the literature search, extracted and summarized the evidence and wrote this article. TO verified the results, and then reviewed, edited and approved the manuscript drafts. Both authors read and approved the final manuscript.

Ethics approval and consent to participate

Not applicable.

\section{Consent for publication}

Not applicable.

\section{Competing interests}

Both authors have lectured for, and received research funding and consulting honoraria from Royal Canin (Aimargues, France) in the last five years.

\section{Publisher's Note}

Springer Nature remains neutral with regard to jurisdictional claims in published maps and institutional affiliations.

\section{Author details}

${ }^{1}$ Medizinische Kleintierklinik, Centre for Clinical Veterinary Medicine, LMU Munich, Veterinaerstrasse 13, 80539 Munich, Germany. 'Department of Clinical Sciences, College of Veterinary Medicine, North Carolina State University, 1060 William Moore Drive, Raleigh, NC 27607, USA. 
Received: 1 June 2018 Accepted: 17 October 2018

Published online: 12 November 2018

\section{References}

1. Olivry T, Deboer DJ, Prelaud P, Bensignor E. International task force on canine atopic dermatitis. Food for thought: pondering the relationship between canine atopic dermatitis and cutaneous adverse food reactions. Vet Dermatol. 2007;18:390-1.

2. Hillier A, Griffin CE. The ACVD task force on canine atopic dermatitis $(X)$ : is there a relationship between canine atopic dermatitis and cutaneous adverse food reactions? Vet Immunol Immunopathol. 2001:81:227-31.

3. Niemic B. Feline inflammatory and ulcerative disease. In: Proceedings of the 25th congress of the European veterinary dentistry society. Dublin: European Veterinary Dental Society; 2016. p. 56-62.

4. White SD, Sequoia D. Food hypersensitivity in cats: 14 cases (1982-1987). J Am Vet Med Assoc. 1989;194:692-5.

5. Vogelnest LJ, Cheng KY. Cutaneous adverse food reactions in cats: retrospective evaluation of 17 cases in a dermatology referral. Population (2001-2011). Austral Vet J. 2013;91:443-51.

6. Leistra M, Willemse T. Double-blind evaluation of two commercial hypoallergenic diets in cats with adverse food reactions. J Fel Med Surg 2002;4:185-8.

7. Hobi S, Linek M, Marignac G, Olivry T, Beco L, Nett C, et al. Clinical characteristics and causes of pruritus in cats: a multicentre study on feline hypersensitivity-associated dermatoses. Vet Dermatol. 2011;22:406-13.

8. Olivry T, Mueller RS, Prelaud P. Critically appraised topic on adverse food reactions of companion. Animals (1): duration of elimination diets. BMC Vet Res. 2015;11:225.

9. Bethlehem S, Bexley J, Mueller RS. Patch testing and allergen-specific serum $\operatorname{lgE}$ and $\lg \mathrm{G}$ antibodies in the diagnosis of canine adverse food reactions. Vet Immunol Immunopathol. 2012;145:582-9.

10. Elwood CM, Rutgers HC, Batt RM. Gastroscopic food sensitivity testing in 17 dogs. J Sm Anim Pract. 1994;35:199-203.

11. Guilford WG, Strombeck DR, Rogers Q, Frick OL, Lawoko C. Development of gastroscopic food sensitivity testing in dogs. J Vet Intern Med. 1994;8: 414-22

12. Hagen-Plantinga EA, Leistra MH, Sinke JD, Vroom MW, Savelkoul HF, Hendriks WH. Measurement of allergen-specific lgG in serum is of limited value for the management of dogs diagnosed with cutaneous adverse food reactions. Vet J. 2017;220:111-6.

13. Ishida R, Masuda K, Kurata K, Ohno K, Tsujimoto H. Lymphocyte blastogenic responses to inciting food allergens in dogs with food hypersensitivity. J Vet Intern Med. 2004;18:25-30.

14. Leistra MH, Markwell PJ, Willemse T. Evaluation of selected-protein-source diets for management of dogs with adverse reactions to foods. J Am Vet Med Assoc. 2001;219:1411-4

15. Loeffler A, Lloyd DH, Bond R, Kim JY, Pfeiffer DU. Dietary trials with a commercial chicken hydrolysate diet in 63 pruritic dogs. Vet Rec. 2004;154:519-22.

16. Mandigers PJJ, Biourge V, van den Ingh TSGAM, Ankringa N, German AJ. A randomized, open-label, positively-controlled field trial of a hydrolyzed protein diet in dogs with chronic small bowel enteropathy. J Vet Intern Med. 2010;24:1350-7.

17. Picco F, Zini E, Nett C, Naegeli C, Bigler B, Rufenacht S, et al. A prospective study on canine atopic dermatitis and food-induced allergic dermatitis in Switzerland. Vet Dermatol. 2008;19:150-5.

18. Puigdemont $A$, Brazis $P$, Serra $M$, Fondati $A$. Immunologic responses against hydrolyzed soy protein in dogs with experimentally induced soy hypersensitivity. Am J Vet Res. 2006;67:484-8.

19. Vaden SL, Hammerberg B, Davenport DJ, Orton SM, Trogdon MM Melgarejo LT, et al. Food hypersensitivity reactions in soft coated wheaten terriers with protein-losing enteropathy or protein-losing nephropathy or both: gastroscopic food sensitivity testing, dietary provocation, and fecal immunoglobulin E. J Vet Intern Med. 2000;14:60-7

20. Guilford WG, Jones BR, Markwell PJ, Arthur DG, Collett MG, Harte JG. Food sensitivity in cats with chronic idiopathic gastrointestinal problems. J Vet Intern Med. 2001;15:7-13.

21. Guilford WG, Markwell PJ, Jones BR, Harte JG, Wills JM. Prevalence and causes of food sensitivity in cats with chronic pruritus, vomiting or diarrhea. J Nutr. 1998;128:2790-1S.
22. Ishida R, Masuda K, Sakaguchi M, Kurata K, Ohno K, Tsujimoto H. Antigenspecific histamine release in dogs with food hypersensitivity. J Vet Med Sci. 2003;65:435-8

23. Johansen C, Mariani C, Mueller RS. Evaluation of canine adverse food reactions by patch testing with single proteins, single carbohydrates and commercial foods. Vet Dermatol. 2017;28:473-81.

24. Loeffler A, Soares-Magalhaes R, Bond R, Lloyd DH. A retrospective analysis of case series using home-prepared and chicken hydrolysate diets in the diagnosis of adverse food reactions in 181 pruritic dogs. Vet Dermatol. 2006;17:273-9.

25. Nichols PR, Morris DO, Beale KM. A retrospective study of canine and feline cutaneous vasculitis. Vet Dermatol. 2001;12:255-64.

26. Proverbio D, Perego R, Spada E, Ferro E. Prevalence of adverse food reactions in 130 dogs in Italy with dermatological signs: a retrospective study. J Small Anim Pract. 2010:51:370-4.

27. Walton GS. Skin responses in the dog and cat to ingested allergens. Observations on one hundred confirmed cases. Vet Rec. 1967;81:709-13.

28. Mandigers PJJ, Biourge V, German AJ. Efficacy of a commercial hydrolysate diet in eight cats suffering from inflammatory bowel disease or adverse reaction to food. Tijdschr Diergeneesk. 2010;135:668-72.

29. Ishida R, Kurata K, Masuda K, Ohno K, Tsujimoto H. Lymphocyte blastogenic responses to food antigens in cats showing clinical symptoms of food hypersensitivity. J Vet Med Sci. 2012;74:821-5.

30. Stogdale L, Bomzon L, Bland van den Berg P. Food allergy in cats. J Am Anim Hosp Assoc. 1982;18:188-94.

31. Guaguere E. Intolérance alimentaire a manifestations cutanées: à propos de 17 cas chez le chat. Prat Med Chir Anim Comp. 1993:28:451-60.

32. Allenspach K, Wieland B, Grone A, Gaschen F. Chronic enteropathies in dogs: evaluation of risk factors for negative outcome. J Vet Intern Med. 2007:21:700-8.

33. Allenspach K, Vaden SL, Harris TS, Grone A, Doherr MG, Griot-Wenk ME, et al. Evaluation of colonoscopic allergen provocation as a diagnostic tool in dogs with proven food hypersensitivity reactions. J Small Anim Pract. 2006; 47:21-6.

34. Cain CL, Bradley CW 2nd, Mauldin EA. Clinical and histologic features of acute-onset erythroderma in dogs with gastrointestinal disease: 18 cases (2005-2015). J Am Vet Med Assoc. 2017;251:1439-49.

35. Carlotti DN, Remy I, Prost C. Food allergy in dogs and cats. A review and report of 43 cases. Vet Dermatol. 1990;1:55-62.

36. Daminet SC. Gluten-sensitive enteropathy in a family of Irish setters. Can Vet J. 1996;37:745-6.

37. Kawano K, Shimakura H, Nagata N, Masashi Y, Suto A, Suto $Y$, et al. Prevalence of food-responsive enteropathy among dogs with chronic enteropathy in Japan. J Vet Med Sci. 2016;78:1377-80.

38. Luckschander N, Allenspach K, Hall J, Seibold F, Grone A, Doherr MG, Gaschen F. Perinuclear antineutrophilic cytoplasmic antibody and response to treatment in diarrheic dogs with food responsive disease or inflammatory bowel disease. J Vet Intern Med. 2006;20:221-7.

39. Rosser EJ Jr. Diagnosis of food allergy in dogs. J Am Vet Med Assoc. 1993; 203:259-62.

40. Rostaher A, Fischer NM, Kummerle-Fraune C, Couturier N, Jacquenet S, Favrot C. Probable walnut-induced anaphylactic reaction in a dog. Vet Dermatol. 2017:28:251-6.

41. Sauter SN, Benyacoub J, Allenspach K, Gaschen F, Ontsouka E, Reuteler G, et al. Effects of probiotic bacteria in dogs with food responsive diarrhoea treated with an elimination diet. J Anim Physiol Anim Nutr (Berl). 2006;90: 269-77.

42. Schreiner NM, Gaschen F, Grone A, Sauter SN, Allenspach K. Clinical signs, histology, and CD3-positive cells before and after treatment of dogs with chronic enteropathies. J Vet Intern Med. 2008:22:1079-83.

43. Tarpataki N, Nagy T. The occurence and the features of food allergy in Hungarian dogs. Vet Dermatol. 2012;23(Suppl. 1):55 (abstract).

44. Volkmann M, Steiner JM, Fosgate GT, Zentek J, Hartmann S, Kohn B. Chronic diarrhea in dogs - retrospective study in 136 cases. J Vet Intern Med. 2017;1: 1043-55.

45. Paterson S. Food hypersensitivity in 20 dogs with skin and gastrointestinal signs. J Small Anim Pract. 1995;36:529-34.

46. Mazzeranghi F, Zanotti C, Di Cerbo A, Verstegen JP, Cocco R, Guidetti G, Canello S. Clinical efficacy of a nutraceutical diet for cats with clinical signs of cutaneous adverse food reaction (CAFR). Pol J Vet Sci. 2017;20:269-76. 
47. Allenspach K, Culverwell C, Chan D. Long-term outcome in dogs with chronic enteropathies: 203 cases. Vet Rec. 2016;178:368.

48. Jeffers JG, Shanley KJ, Meyer EK. Diagnostic testing of dogs for food hypersensitivity. J Am Vet Med Assoc. 1991;198:245-50.

49. Lowrie M, Garden OA, Hadjivassiliou M, Harvey RJ, Sanders DS, Powell R, Garosi L. The clinical and serological effect of a gluten-free diet in border terriers with Epileptoid cramping syndrome. J Vet Intern Med. 2015;29:1564-8.

50. Mueller RS, Friend S, Shipstone MA, Burton G. Diagnosis of claw disease - a prospective study of 24 dogs. Vet Dermatol. 2000;11:133-41.

51. Walton GS, Parish WE, Coombs RRA. Spontaneous allergic dermatitis and enteritis in a cat. Vet Rec. 1968:83:35-41.

Ready to submit your research? Choose BMC and benefit from:

- fast, convenient online submission

- thorough peer review by experienced researchers in your field

- rapid publication on acceptance

- support for research data, including large and complex data types

- gold Open Access which fosters wider collaboration and increased citations

- maximum visibility for your research: over $100 \mathrm{M}$ website views per year

At $\mathrm{BMC}$, research is always in progress.

Learn more biomedcentral.com/submissions 